\title{
Inhibitory effect of BMAP-28 on Leptospiral Lipopolysaccharide-Induced TLR2-Dependent Immune Response in Bovine Cells
}

\author{
Yijie GUO, ${ }^{1,2,}{ }^{*}$ Cuiping Ding, ${ }^{1}$ Bo Zhang, ${ }^{2}$ Jun XU, ${ }^{3}$ Meng XUN, ${ }^{1}$ and Jiru XU1 \\ ${ }^{1}$ Department of Pathogenic Microbiology and Immunology, School of Basic Medical Sciences, Xi'an Jiao Tong University, Xi'an, China \\ ${ }^{2}$ Graduate School of Agricultural Science, Tohoku University, Sendai, Japan \\ ${ }^{3}$ Faculty of Science and Engineering, Iwate University, Iwate, Japan \\ "Corresponding author: Yijie GUO, Department of Pathogenic Microbiology and Immunology, School of Basic Medical Sciences, Xi'an Jiao Tong University, Xi'an, China. Tel: \\ +86-2985267814, Fax: +86-2985267814, E-mail: yijie_guo@ xjtu.edu.cn
}

Received 2015 October 27; Revised 2016 June 03; Accepted 2016 June 15.

\begin{abstract}
Background: Bovine leptospirosis is a widespread zoonotic disease, leading to serious economic losses in animal production and causing potential hazards to human health. Leptospiral lipopolysaccharide (L-LPS) plays an important role in leptospirosis pathogenicity.

Objectives: With respect to L-LPS endotoxin-like activity, we examined bovine immune response to L-LPS and the inhibitory ability of bovine myeloid antimicrobial peptide-28 (BMAP-28) against L-LPS-induced immune activation in bovine cells.

Materials and Methods: In this study, L-LPS-induced proinflammatory cytokine production in bovine cells was quantitatively measured with real-time PCR and ELISA, and we determined which cell membrane receptors (toll-like receptor [TLR]2 and TLR4) played a major role. In addition, the ability of BMAP-28 to inhibit L-LPS-induced endotoxin-like immune activation in bovine cells was determined by the decrease in cytokine secretion.

Results: L-LPS showed the ability to induce cytokine production in bovine cells, and its induction was TLR2-dependent. BMAP-28 was used to inhibit L-LPS-induced endotoxin-like activity. The function of BMAP-28 was to inhibit LPS-induced TLR2 expression and cytokine production.

Conclusions: In this study, the L-LPS immune response of bovine cells was significant, indicating that TLR2 is the predominant receptor for L-LPS. Due to L-LPS endotoxin-like activity, we found a strategy through using BMAP-28 to prevent L-LPS-induced TLR2dependent immune activation in bovine cells.
\end{abstract}

Keywords: LPS, Toll-Like Receptor 2, Cytokines, BMAP-28, Cattle, Leptospira

\section{Background}

Leptospirosis is a global zoonotic disease caused by pathogenic organisms of the genus Leptospira, mostly found in tropical and subtropical countries (1). Based on agglutinating lipopolysaccharide (LPS) antigens, pathogenic Leptospira can be divided into more than 300 serovars belonging to different serogroups (2). Leptospira interrogans serovar hardjo and L. borgpetersenii serovar hardjo are the predominant pathogenic species of cattle leptospirosis in China (3-5). The symptoms of infected cattle do not frequently develop into typical signs of acute leptospirosis. However, reproductive failure and spontaneous abortion are the most common clinical signs. Bovine leptospirosis could affect growth in cattle production and is easily transmitted to humans through direct or indirect transmission from the infected outer environment (6-8).

As one of the major outer-membrane components in Leptospira, LPS can affect the virulence of pathogenic Leptospira (9). Leptospiral LPS (L-LPS) exhibits a speciesspecific immune response through toll-like receptors (TLRs). Murine cells can activate an immune response through TLR2 and TLR4 under L-LPS stimulation, but only through human TLR2 during a Leptospira infection(10). Until now, the function of TLRs in bovine innate immunity during Leptospira infections has been unclear. In this study, we employed bovine fetal fibroblasts (BFF_NCC1) to elucidate the main function of TLR2 in bovine innate immunity during Leptospira infections.

Isogai et al. (4) reported that L-LPS shows endotoxinlike activity similar to that of Escherichia coli LPS. After LLPS stimulation, various proinflammatory cytokines are secreted. Due to the imbalanced or overwhelming production of these cytokines, leptospirosis may lead to septic shock, such as leptospiral uveitis (11) and liver necrosis (12).

Recent studies have demonstrated that cathelicidin- 
derived antimicrobial peptides, including LL-37 (human), RCAP18 (rabbit), bovine myeloid antimicrobial peptide-28 (BMAP-28), and SMAP-29 (sheep), have the ability to inhibit LPS-induced cytokine secretion through direct binding to LPS or blocking the binding of LPS to LPS-binding protein (LBP) (13-15). Due to these characteristics, these peptides have become potential drug candidates for the treatment of Gram-negative bacteria-induced endotoxin shock and sepsis. However, the inhibiting effect of BMAP-28 on the interaction between L-LPS and bovine cells is still vague.

\section{Objectives}

In this study, we employed BFF_NCC1 cells to verify the function of TLR2 in bovine innate immunity during Leptospira infections. In addition, we determined whether BMAP-28 could inhibit the toxicity of L-LPS by decreasing the TLR2-dependent cytokine expression in bovine cells. This approach might lead to an alternative therapy compared to risky antibiotic treatments.

\section{Materials and Methods}

\subsection{Preparation of Leptospiral LPS}

Leptospira interrogans serovar hardjo was cultured in Ellinghausen-McCullough-Johnson-Harris medium (EMJH; Difco, USA) supplemented with 10\% normal rabbit serum (Gibco, USA) at $28^{\circ} \mathrm{C}$ for 7 days. The L-LPS was extracted using the method of Isogai et al. (4). Escherichia coli serotype O111:B4 LPS (E-LPS; Sigma-Aldrich, USA) was used as a positive control.

\subsection{Peptide Preparation}

BMAP-28 (sequences: GGLRSLGRKILRAWKKYGPIIVPIIRI) was produced using the method of Isogai et al. (16). Briefly, the peptide was synthesized with the solid-phase methodology, and purified with reverse-phase high-performance liquid chromatography (Shimadzu, Japan). It was suspended in Hanks' balanced salt solution (Gibco, USA) and stored at $-20^{\circ} \mathrm{C}$. Unfolded BMAP-28 (UBMAP-28) was used as the negative control peptide.

\subsection{Cell Culture and LPS Stimulation}

The BFF_NCC1 cells were kindly provided by Prof. Fukuda (17). Cells were cultured in DMEM culture medium (Nacalai-tesque, Japan) including 10\% fetal bovine serum (FBS; Biowest SAS, France) and 1\% antibiotic and antimycotic solution (Nacalai-tesque, Japan). The cells $(1 \times 106$ cells/well) were suspended in 6-well plates and cultured overnight at $37^{\circ} \mathrm{C}$ in $5 \% \mathrm{CO}_{2}$. The culture medium was then transferred to antibiotic-free medium for 2 hours before LPS stimulation. The unstimulated well was used as a control. The present study was approved by the ethics committee of Xi'an Jiaotong university faculty of medicine (2014027).

\subsection{RNA Extraction, cDNA Preparation and Real-Time Poly-} merase Chain Reaction

Total RNA was isolated from the bovine cells according to the protocol of the NucleoSpin RNA II kit (Takara Bio, Japan). The total RNA was reverse-transcribed into cDNA using a PrimeScript RT reagent kit (Takara Bio, Japan), and $1 \mu \mathrm{g}$ of cDNA was used for the quantitative real-time polymerase chain reaction ( $q R T-P C R$ ) performed on a thermal cycler dice real-time PCR system II (Takara Bio, Japan). SYBR Premix ExTaq II and the primers listed in Table 1 were used in this study. The amplification condition of qRT-PCR was performed as follows: $3 \mathrm{~min}$ at $95^{\circ} \mathrm{C}$, and 40 cycles at $95^{\circ} \mathrm{C}$ for $15 \mathrm{~s}$ and $60^{\circ} \mathrm{C}$ for 1 minutes. The final results were exported as the relative expression level, and the $\beta$-actin gene was detected as an internal standard. In order to visualize the qRT-PCR results for TLR4, $10 \mu \mathrm{L}$ of the qRT-PCR reaction was electrophoresed in 10\% Del-gel (Kitasato Medical Service, Japan) and stained with GelRed (Biotium, USA). Bovine peripheral blood mononuclear cells (PBMCs) were used as positive controls (18).

\subsection{Western Blotting Analysis}

Total proteins were obtained from bovine cells with lysine solution (50 mM Tris- $\mathrm{HCl}, 0.15 \mathrm{M} \mathrm{NaCl}, 1 \%$ Triton X-100, $2.5 \mathrm{mg} / \mathrm{mL}$ sodium deoxycholate, and a protease inhibitor cocktail from Nacalai-tesque). The total protein concentrations were calibrated by a DC Protein assay reagent (BioRad, USA). Next, $10 \mu \mathrm{g}$ of protein was subjected to SDSPAGE (ATTO, Japan) and blotted onto polyvinylidene fluoride membrane (Millipore, USA) as described previously (19). Lastly, the ECL chemiluminescence Western blot system was used to detect the protein expression level. The expression of $\beta$-actin (Santa Cruz, CA, USA) was used as a loading control.

\subsection{Enzyme-Linked Immunosorbent Assay}

The cytokine (TNF- $\alpha$ and IL-6) secretion of bovine cells was measured by following the instructions for bovine enzyme-linked immunosorbent assay kits (ELISA; R and D, USA). The optical density values were observed at 450 $\mathrm{nm}$ wavelengths in an ELISA plate reader. The concentrations of samples were calculated by known standards in Microsoft Excel. Each sample was measured twice to ensure the reproducibility of the experiment. 
Table 1. Primers Used in This Study

\begin{tabular}{llll}
\hline Gene & Forward & Reverse & Accession No. \\
\hline TLR2 & TCTGCTACGACGCCTTCGT & GCTCCTGGACCATGAGGTTCT & NM174197.2 \\
TLR4 & AGCAGATGCAGAAACCAACC & TGGTACATGGCGGCATTTAC & NM174198 \\
$\beta$-actin & TTTTTGGCGCTTGACTCAGG & TTGGGAATGCTCGATCCAAC & AY141970.1 \\
\hline
\end{tabular}

\subsection{Statistical Analysis}

Three independent experiments were performed for each assay. The mathematical results were displayed as mean \pm standard deviation. The P-value was calculated using Steel's test in GraphPad Prism 6 software. The values of $\mathrm{P}<0.05\left(^{*}\right)$ and $\mathrm{P}<0.01\left(^{* *}\right)$ were considered as statistically significant.

\section{Results}

To examine the bovine cellular inflammatory response triggered by L-LPS, the ELISA method was applied to analyze the amount of TNF- $\alpha$ and IL- 6 secretion in the BFF_NCC1 cell culture supernatant. As shown in Figure 1, these cytokines were significantly up-regulated either by L-LPS and E-LPS stimulations $(\mathrm{P}<0.05)$. After the L-LPS stimulations, the TNF- $\alpha$ secretion level increased to a peak when using $10 \mu \mathrm{g} / \mathrm{mL}$ L-LPS. It then decreased slightly at $100 \mu \mathrm{g} / \mathrm{mL}$ of L-LPS stimulation (Figure 1A). IL-6 secretion was stably enhanced following the increased dose of L-LPS (Figure 1B). In the time-dependent experiment of L-LPS stimulation, the secretion levels of TNF- $\alpha$ and IL- 6 reached the highest level at $6 \mathrm{~h}$ and maintained that level for 24 hours.

The TLR2 and TLR4 mRNA expressions in cultured BFF_NCC1 cells were analyzed by qRT-PCR. Figure 2 shows that PBMCs can express 237-bp TLR4 mRNA, but BFF_NCC1 cells did not express such mRNA. Therefore, the BFF_NCC1 cells could be used as a good cell model for studying the immune response through TLR2.

As shown in Figure 3A, we examined the mRNA expression of TLR2 in response to various concentrations of LLPS in BFF_NCC1 cells. After the stimulation of L-LPS, the TLR2 mRNA expression level was significantly increased in a dose-dependent manner $(\mathrm{P}<0.05)$. The relative increase of the TLR2 mRNA expression level in L-LPS stimulated cells reached 1.9-fold compared with unstimulated cells. As a positive control, E-LPS induced up-regulation of TLR2 mRNA expression (1.5 - 2.1-fold) at doses ranging from 1 to $100 \mu \mathrm{g} / \mathrm{mL}(\mathrm{P}<0.05)$. As shown in Figure 3B, the time-dependent regulation of TLR2 mRNA expression was also tested in BFF_NCC1 cells under $1 \mu \mathrm{g} / \mathrm{mL}$ of L-LPS stimulation. In cells incubated with $1 \mu \mathrm{g} / \mathrm{mL}$ of L-LPS, the TLR2 mRNA expression was obviously up-regulated 1.5-fold at 6 hours and was then stably expressed for 24 hours $(\mathrm{P}<$ 0.05). When the cells were incubated with E-LPS, the TLR2 mRNA expression level was higher than with L-LPS stimulation $(\mathrm{P}<0.05)$. These results indicated that TLR2 might be the major receptor in the bovine innate immune response to L-LPS stimulation.

To ensure the up-regulation of TLR2 after L-LPS stimulation in the BFF_NCC1 cells, the protein expression level of TLR2 was examined with Western blotting (Figure 4). The expression level of TLR2 protein was increased after 1 $\mu \mathrm{g} / \mathrm{mL}$ of L-LPS stimulation at 6 hours, and it showed a stably low expression level in unstimulated BFF_NCC1 cells. Based on the density measurement of protein bands, the expression level of TLR2 protein in L-LPS-stimulated cells was approximately 2.4 -fold greater than that of unstimulated cells.

Our research showed that TNF- $\alpha$ and IL- 6 are two important inflammatory products in the bovine innate immune response to L-LPS stimulation. In order to assess the inhibitory effect of BMAP-28 on L-LPS-induced cytokine production in BFF_NCC1 cells, the cells were cultured with both L-LPS and BMAP-28 at $10 \mu \mathrm{g} / \mathrm{mL}$ for 6 hours (Figure 5). With the incubation of BMAP-28, enhancement of TNF- $\alpha$ and IL-6 was entirely inhibited compared to that of L-LPSstimulated cells. When BMAP-28 was replaced with uBMAP28 , there was no effect on TNF- $\alpha$ and IL- 6 mRNA expression induced by L-LPS.

To examine whether the cytokine inhibitory effect of BMAP-28 was related to TLR2, the TLR2 mRNA expression was tested (Figure 6). The up-regulation of TLR2 mRNA was completely inhibited by BMAP-28 compared to that of L-LPS stimulated cells. There was no effect on the L-LPS-induced TLR2 mRNA expression by replacing BMAP-28 with uBMAP28.

\section{Discussion}

In this study, the bovine cellular immune response to L-LPS was examined. We found that there was rapid upregulation of proinflammatory cytokines at low concentrations of L-LPS stimulation in BFF_NCC1 cells. In previous studies, LPS from Leptospira species had a specific immune 
A

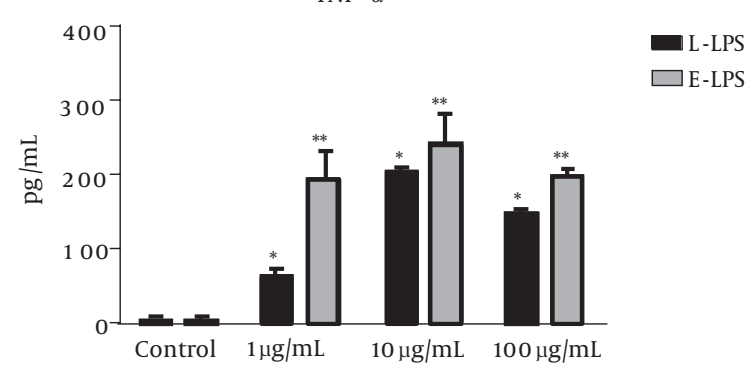

C

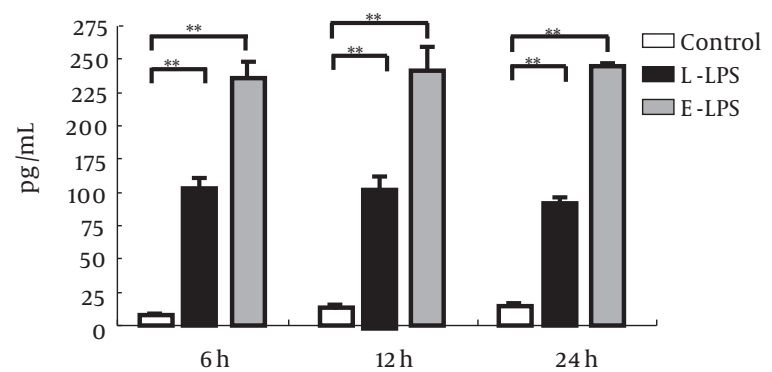

B

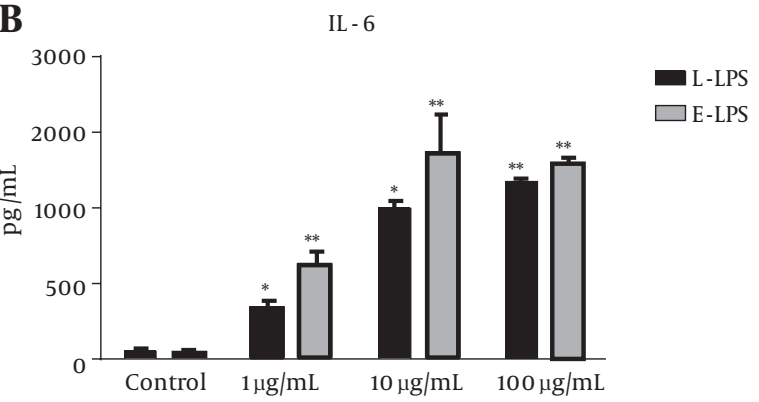

D

IL - 6

For the dose experiment, the cell supernatant fluids were collected at 6 hours after incubation with 1,10, and $100 \mu \mathrm{g} / \mathrm{mL}$ concentrations of LPS. (A) TNF- $\alpha$, (B) IL-6. For the time experiment, cell supernatant fluids were collected at 6,12 , and $24 \mathrm{~h}$ after incubation with concentrations of $1 \mu \mathrm{g} / \mathrm{mL}$ of LPS. (C) TNF- $\alpha$, (D) IL-6. The data are shown as an average of biological replicates \pm SD. Asterisks indicate significant differences $\left({ }^{*} \mathrm{P}<0.05,{ }^{* *} \mathrm{P}<0.01\right)$.

Figure 2. Detection of TLR4 mRNA Expression on Different Kinds of Cattle Cells by qRT-PCR Analysis

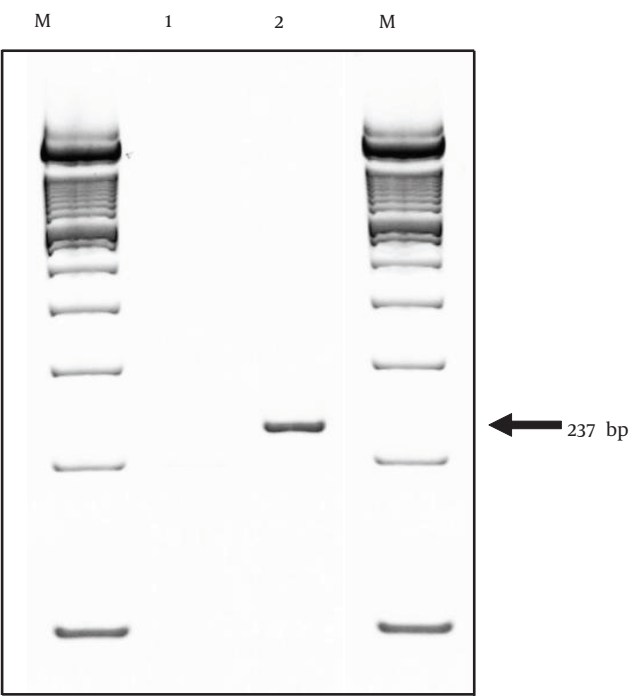

Lane 1, BFF_NCC1 cells; lane 2, PBMCs; M, marker (100-bp DNA ladder). response, which was recognized by TLR2 in human monocytes, TLR2 in pig fibroblasts, and both TLR2 and TLR4 in mouse macrophages $(10,20)$. To elucidate whether TLR2 plays an important role in the activation response of L-LPS in bovine cells, in the present study, BFF_NCC1 cells were used as a cell model based on certain characteristics (high expression level of TLR2 and lack of TLR4 mRNA expression). By analyzing TLR2 expression on BFF_NCC1 cells after L-LPS stimulation, we found that the expression levels of TLR2 mRNA and protein increased rapidly even at the low dose of L-LPS. These results indicated that TLR2 could be the major cell membrane receptor in the bovine innate immune response to Leptospira infection.

An earlier study reported that L-LPS has endotoxin-like activity similar to the LPS of Escherichia coli (4) Leptospirainfected hamsters showed massively high expression of cytokines in the kidneys (21). Patients with leptospirosis, which is associated with severe and fatal diseases, have a higher expression of IL-6, IL-8, and IL-1 $\beta$ (22). Previous studies indicated that the immune response to Leptospira could cause organ damage in Leptospira infections $(23,24)$. Moreover, due to the Jarisch-Herxheimer reaction that can occur with the antibiotic treatment of patients with leptospiro- 
Figure 3. The ratio of TLR2 mRNA Expression was Quantified with qRT-PCR in LPSInduced BFF_NCC1 Cells

A

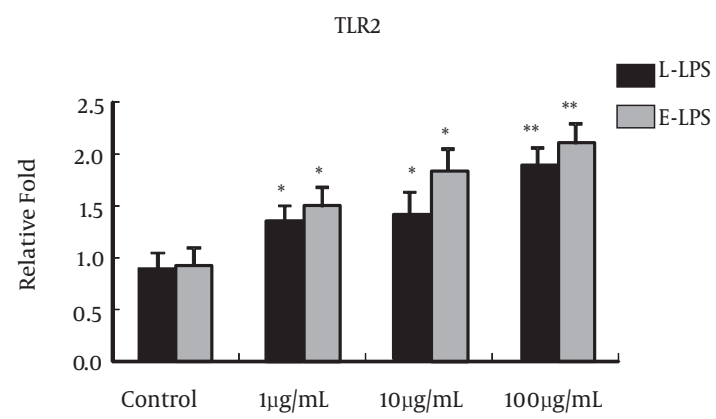

B

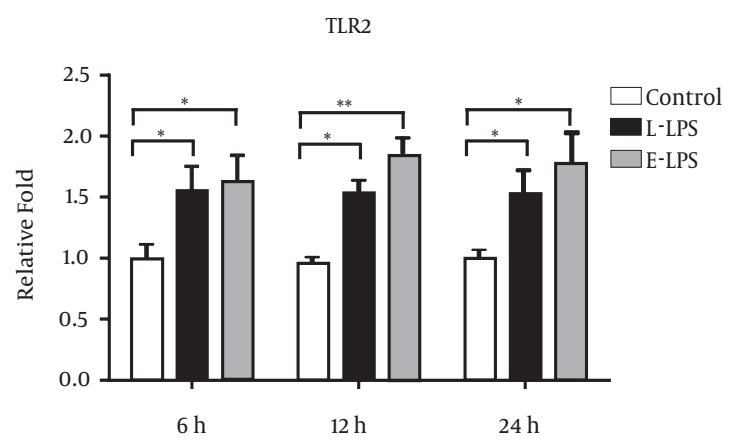

A, Cells were isolated after incubation with 1,10 , and $100 \mu \mathrm{g} / \mathrm{mL}$ concentrations of LPS at 6 hours; B, cells were isolated at 6, 12, and 24 hours after incubation with 1 $\mu \mathrm{g} / \mathrm{mL}$ of LPS. Data are shown as averages of biological replicates \pm SD. Asterisks indicate significant differences $\left({ }^{*} \mathrm{P}<0.05,{ }^{* *} \mathrm{P}<0.01\right)$.

Figure 4. TLR2 Protein Expression After Exposure to L-LPS in BFF_NCC1 Cells, Based on Western Blotting Analysis
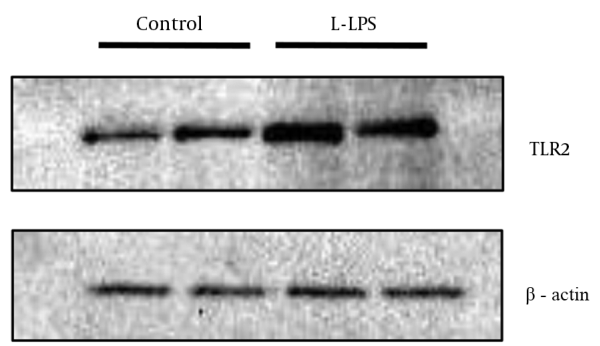

Cells were stimulated by $1 \mu \mathrm{g} / \mathrm{mL}$ of L-LPS for 6 hours. Unstimulated cells were used as a control. The two lanes shown for the respective experimental conditions are the results obtained from duplicate experiments in which the cells were separately prepared. Anti- $\beta$-actin polyclonal antibody was used to detect $\beta$-actin as a loading control.
Figure 5. Effects of BMAP-28 Against L-LPS on Cytokine Expression in BFF_NCC1 Cells
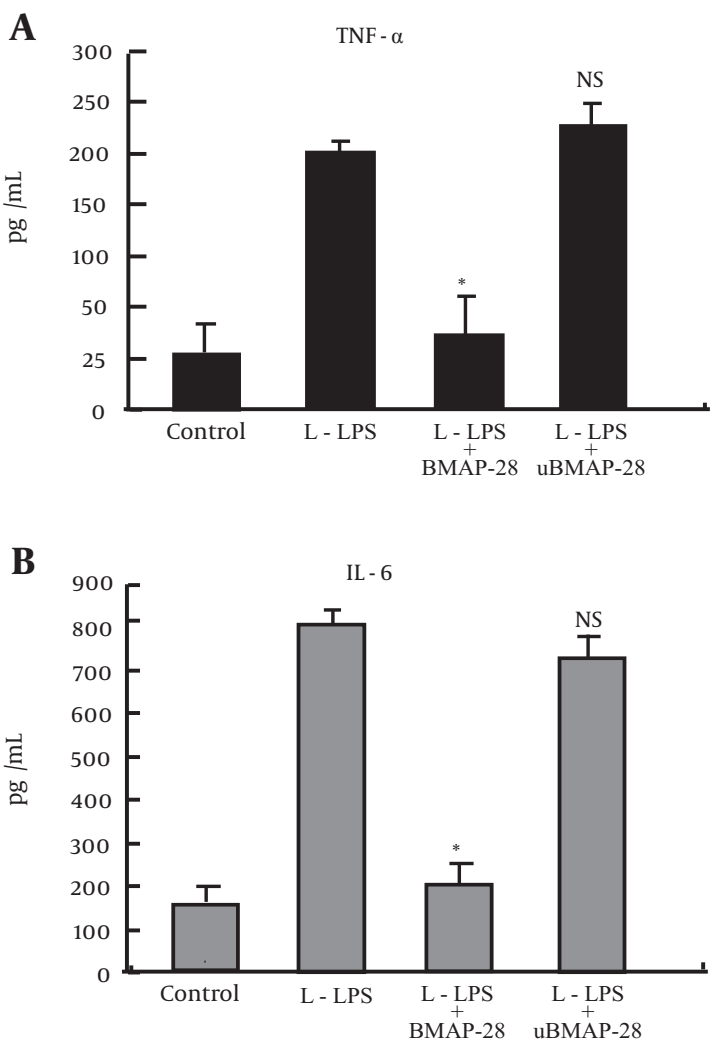

Cells were incubated with $10.0 \mu \mathrm{g} / \mathrm{mL}$ of L-LPS alone or with $10.0 \mu \mathrm{g} / \mathrm{mL}$ BMAP-28 or uBMAP-28 for $6 \mathrm{~h}$. Statistical analyses were performed between cells stimulated by L-LPS alone or with peptides and unstimulated cells. Asterisks indicate significant differences $\left({ }^{*} \mathrm{P}<0.05,{ }^{* *} \mathrm{P}<0.01\right)$. NS means no significant difference between L-LPS plus peptide groups and unstimulated ones.

sis $(25,26)$, new strategies are needed.

Antimicrobial peptides that reduce or prevent the presentation of LPS to its predominant receptors can be applied to ease the immunological response to sepsis caused by Gram-negative bacteria $(27,28)$. Therefore, BMAP-28's inhibitory effect on Leptospira infections was tested at the cellular level, and we found that it is capable of inhibiting L-LPS-induced cellular cytokine release in BFF_NCC1 cells, which was supported by earlier research (28). In this study, we also determined that BMAP-28 could mediate TLR2 expression, leading to inhibition of the proinflammatory cytokine response (27). This gives us an alternative approach to reducing the occurrence of antibiotic-triggered endotoxin shock.

In summary, these results indicate that TLR2 is the predominant function in bovine innate immunity during Leptospira infections. Furthermore, we found that BMAP-28 can prevent L-LPS-induced TLR2 and cytokine expression 


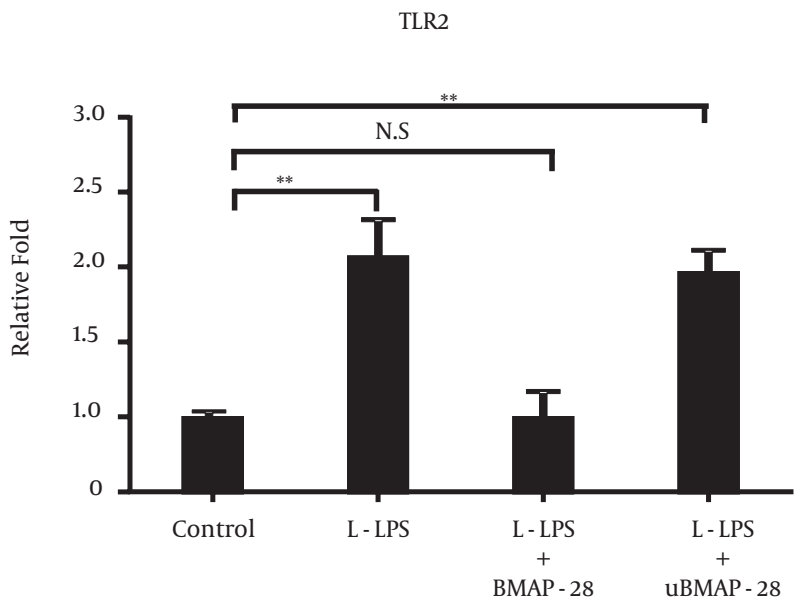

Cells were incubated with $10.0 \mu \mathrm{g} / \mathrm{mL}$ of L-LPS alone or with L-LPS plus BMAP-28 (10.0 $\mu \mathrm{g} / \mathrm{mL})$ or uBMAP-28 $(10.0 \mu \mathrm{g} / \mathrm{mL})$ for 6 hours. Statistical analyses were performed between cells stimulated by L-LPS alone or with BMAP-28 and unstimulated cells. Asterisks indicate significant differences $\left({ }^{*} \mathrm{P}<0.05,{ }^{* *} \mathrm{P}<0.01\right)$. NS means no significant difference between L-LPS plus BMAP-28 and unstimulated ones.

in bovine cells. The strategy of using BMAP-28 may provide useful information for the development of novel antiinfective and immunomodulatory agents.

\section{Acknowledgments}

We are grateful to associate Prof. Fukuda (graduate school of agriculture science, Tohoku University, Japan) for providing the BFF_NCC1 cell line, and to Prof. Isogai (graduate school of agriculture science, Tohoku university, Japan) for critically reading the manuscript.

\section{Footnotes}

Authors' Contribution: Yijie Guo and Jiru Xu designed the experiment, Yijie Guo and Cuiping Ding participated in the experimental operation, Bo Zhang and Meng Xun provided help in the data analysis, and Jun Xu drafted the manuscript.

Financial Disclosure: The authors declare that no competing financial interests exist.

Funding/Support: This study was supported by the China postdoctoral science foundation (2015M582672) and the natural science basic research plan in ShaanXi province of China (2016JQ8051).

\section{References}

1. Brenner DJ, Kaufmann AF, Sulzer KR, Steigerwalt AG, Rogers FC, Weyant RS. Further determination of DNA relatedness between serogroups and serovars in the family Leptospiraceae with a proposal for Leptospira alexanderi sp. nov. and four new Leptospira genomospecies. Int J Syst Bacteriol. 1999;49 Pt 2:839-58. doi: 10.1099/0020771349-2-839. [PubMed: 10319510].

2. Adler B, de la Pena Moctezuma A. Leptospira and leptospirosis. Vet Microbiol. 2010;140(3-4):287-96. doi: 10.1016/j.vetmic.2009.03.012. [PubMed: 19345023].

3. Hu W, Lin X, Yan J. Leptospira and leptospirosis in China. Curr Opin Infect Dis. 2014;27(5):432-6. doi: 10.1097/QCO.0000000000000097. [PubMed: 25061933].

4. Isogai $\mathrm{E}$, Isogai $\mathrm{H}$, Kurebayashi $\mathrm{Y}$, Ito N. Biological activities of leptospiral lipopolysaccharide. Zentralbl Bakteriol Mikrobiol Hyg A. 1986;261(1):53-64. [PubMed:3518294].

5. Victoriano AF, Smythe LD, Gloriani-Barzaga N, Cavinta LL, Kasai T, Limpakarnjanarat K, et al. Leptospirosis in the Asia Pacific region. BMC Infect Dis. 2009;9:147. doi: 10.1186/1471-2334-9-147. [PubMed: 19732423]

6. Cortese VS, Gallo GF, Cleary DL, Galvin JE, Leyh RD. Efficacy of a flexible schedule for administration of a Leptospira borgpetersenii serovar Hardjo bacterin to beef calves. Am J Vet Res. 2014;75(5):507-12. doi: 10.2460/ajvr.75.5.507. [PubMed: 24762025].

7. Dreyfus A, Heuer C, Wilson P, Collins-Emerson J, Baker MG, Benschop J. Risk of infection and associated influenza-like disease among abattoir workers due to two Leptospira species. Epidemiol Infect. 2015;143(10):2095-105. doi: 10.1017/S0950268814002477. [PubMed: 25266854].

8. Lilenbaum W, Martins G. Leptospirosis in cattle: a challenging scenario for the understanding of the epidemiology. Transbound Emerg Dis. 2014;61 Suppl 1:63-8. doi:10.1111/tbed.12233. [PubMed: 25135465].

9. Murray GL, Srikram A, Henry R, Hartskeerl RA, Sermswan RW, Adler B. Mutations affecting Leptospira interrogans lipopolysaccharide attenuate virulence. Mol Microbiol. 2010;78(3):701-9. doi: 10.1111/j.13652958.2010.07360.x. [PubMed: 20807198].

10. Werts C, Tapping RI, Mathison JC, Chuang TH, Kravchenko V, Saint Girons I, et al. Leptospiral lipopolysaccharide activates cells through a TLR2-dependent mechanism. Nat Immunol. 2001;2(4):346-52. doi: 10.1038/86354. [PubMed: 11276206]. 
11. Priya CG, Rathinam SR, Muthukkaruppan V. Evidence for endotoxin as a causative factor for leptospiral uveitis in humans. Invest Ophthalmol Vis Sci. 2008;49(12):5419-24. doi: 10.1167/iovs.08-2174. [PubMed: 18658094].

12. Isogai E, Isogai H, Fujii N, Oguma K. Macrophage activation by leptospiral lipopolysaccharide. Zentralbl Bakteriol. 1990;273(2):200-8. [PubMed: 1698063].

13. Bowdish DM, Davidson DJ, Scott MG, Hancock RE. Immunomodulatory activities of small host defense peptides. Antimicrob Agents Chemother. 2005;49(5):1727-32. doi: 10.1128/AAC.49.5.1727-1732.2005. [PubMed: 15855488].

14. Zughaier SM, Shafer WM, Stephens DS. Antimicrobial peptides and endotoxin inhibit cytokine and nitric oxide release but amplify respiratory burst response in human and murine macrophages. Cell Microbiol. 2005;7(9):1251-62. doi:10.1111/j.1462-5822.2005.00549.x. [PubMed: 16098213].

15. Rosenfeld Y, Papo N, Shai Y. Endotoxin (lipopolysaccharide) neutralization by innate immunity host-defense peptides. Peptide properties and plausible modes of action. J Biol Chem. 2006;281(3):1636-43. doi: 10.1074/jbc.M504327200. [PubMed:16293630].

16. Isogai $\mathrm{E}$, Isogai $\mathrm{H}$, Takahashi K, Kobayashi-Sakamoto M, Okumura K. Antimicrobial activity of three tick defensins and four mammalian cathelicidin-derived synthetic peptides against Lyme disease spirochetes and bacteria isolated from the midgut. Exp Appl Acarol. 2009;49(3):221-8. doi: 10.1007/s10493-009-9251-5. [PubMed: 19229642].

17. Donai K, Kiyono T, Eitsuka T, Guo Y, Kuroda K, Sone H, et al. Bovine and porcine fibroblasts can be immortalized with intact karyotype by the expression of mutant cyclin dependent kinase 4, cyclin D, and telomerase. J Biotechnol. 2014;176:50-7. doi: 10.1016/j.jbiotec.2014.02.017. [PubMed: 24589663].

18. Guo Y, Zhao G, Tanaka S, Yamaguchi T. Differential responses between monocytes and monocyte-derived macrophages for lipopolysaccharide stimulation of calves. Cell Mol Immunol. 2009;6(3):223-9. doi 10.1038/cmi.2009.30. [PubMed: 19567206].

19. Fukuda T, Tani Y, Kobayashi T, Hirayama Y, Hino O. A new Western blotting method using polymer immunocomplexes: detection of Tsc1 and Tsc2 expression in various cultured cell lines. Anal Biochem.
2000;285(2):274-6. doi: 10.1006/abio.2000.4787. [PubMed: 11017715]. 20. Guo Y, Fukuda T, Donai K, Kuroda K, Masuda M, Nakamura S, et al. Leptospiral lipopolysaccharide stimulates the expression of toll-like receptor 2 and cytokines in pig fibroblasts. Anim SciJ. 2015;86(2):238-44. doi: 10.1111/asj.12254. [PubMed: 25039909].

21. Lowanitchapat A, Payungporn S, Sereemaspun A, Ekpo P, Phulsuksombati D, Poovorawan Y, et al. Expression of TNF-alpha, TGF-beta, IP10 and IL-10 mRNA in kidneys of hamsters infected with pathogenic Leptospira. Comp Immunol Microbiol Infect Dis. 2010;33(5):423-34. doi: 10.1016/j.cimid.2009.05.001. [PubMed: 19559480].

22. Wagenaar JF, Gasem MH, Goris MG, Leeflang M, Hartskeerl RA, van der Poll T, et al. Soluble ST2 levels are associated with bleeding in patients with severe Leptospirosis. PLoS Negl Trop Dis. 2009;3(6):eee453. doi: 10.1371/journal.pntd.0000453. [PubMed: 19488407].

23. de Fost M, Hartskeerl RA, Groenendijk MR, van der Poll T. Interleukin 12 in part regulates gamma interferon release in human whole blood stimulated with Leptospira interrogans. Clin Diagn Lab Immunol. 2003;10(2):332-5. [PubMed: 12626464].

24. Yan W, Faisal SM, McDonough SP, Divers T], Barr SC, Chang CF, et al. Immunogenicity and protective efficacy of recombinant Leptospira immunoglobulin-like protein B (rLigB) in a hamster challenge model. Microbes Infect. 2009;11(2):230-7. doi: 10.1016/j.micinf.2008.11.008. [PubMed:19070678].

25. Guerrier G, D'Ortenzio E. The Jarisch-Herxheimer reaction in leptospirosis: a systematic review. PLoS One. 2013;8(3):eee59266. doi: 10.1371/journal.pone.0059266. [PubMed: 23555644].

26. Vaughan C, Cronin CC, Walsh EK, Whelton M. The Jarisch-Herxheimer reaction in leptospirosis. Postgrad Med J. 1994;70(820):118-21. [PubMed: 8170883].

27. D'Este F, Tomasinsig L, Skerlavaj B, Zanetti M. Modulation of cytokine gene expression by cathelicidin BMAP-28 in LPS-stimulated and unstimulated macrophages. Immunobiology. 2012;217(10):962-71. doi: 10.1016/j.imbio.2012.01.010. [PubMed: 22317752].

28. Lee EK, Kim YC, Nan YH, Shin SY. Cell selectivity, mechanism of action and LPS-neutralizing activity of bovine myeloid antimicrobial peptide-18 (BMAP-18) and its analogs. Peptides. 2011;32(6):1123-30. doi: 10.1016/j.peptides.2011.03.024. [PubMed: 21497177]. 